\title{
CYTOMORPHOLOGICAL INVESTIGATIONS IN OXYRIA DIGYNA HILL. FROM THE KASHMIR HIMALAYA, INDIA
}

\begin{abstract}
In the present paper, detailed cytomorphological investigations in Oxyria digyna Hill. from Kashmir Himalaya-India have been reported for the first time. All the of 14 investigated populations of $O$. digyna are diploid based on $x=7$. Out of these in two populations $0-2 B$ chromosomes have been recorded for the first time while 6 populations differed significantly in their meiotic characteristics. Meiotic abnormalities during male meiosis observed include inter PMC chromatin transfer (cytomixis). Non-synchronous disjunction of some bivalents, laggards and bridges at anaphases and telophases. Consequent to these meiotic anomalies, microsporogenesis in meiocytes is abnormal resulting in to dyads, triads and polyads with or without micronuclei. The overall effect is seen in reduced pollen fertility. Unreduced pollen grains were observed in some populations, which differed significantly in their size compared to the normal (reduced) pollen grains. It is observed that a smaller frequency of pollen grains differed morphologically in Aharbal and Yosmarg populations. The remaining eight populations showed regular meiotic course, normal microsporogenesis and high percentage of pollen fertility (95.09-99.09\%).
\end{abstract}

Key words: Oxyria digyna, cytomorphology, B-chromosomes, meiotic abnormalities.

Introduction. The mountain Sorrel (Oxyria digyna Hill.), a monotypic species of family Polygonaceae is a succulent herb having rounded, cordate or reniform mostly radical leaves and greenish or reddish flowers borne in panicles. In India, it is found in the higher reaches of Himalayas from Kashmir to Sikkim and flowers from May-July. The herb has antiscorbutic and refrigent properties $[1,2]$. Its leaf extract is used to improve digestion by tribals in Ladakh [3, 4]. It is a highly cold tolerant species and can survive under continuous snow cover for two to three years in succession [5]. The different populations of the species are quite distinct morphologically and show considerable variation in leaf size, stem / petiole colour and inflorescence size, etc. Cytological data have aided or even made possible taxonomic decisions for example in tracing the origin of hybrids. Though the available literature indicates that the species has been cytologically investigated across the world but

(c) UMER FAROOQ, M.I.S. SAGGOO, 2014 no chromosomal information is available about Indian germplasm of $O$. digyna. To fill in the lacunae, therefore, the present study on meiotic analysis of 14 populations of this species from Kashmir Himalaya was undertaken to understand the cytological status of this species.

Materials and methods. The plant material was collected from the wild populations of $O$. digyna from Kashmir and cold deserts of Ladakh ( $\mathrm{J}$ \& K), India (Fig. 1) during the months of May-July over a period of three years (2008-2011). The voucher specimens of all the cytologically studied populations have been deposited in the Herbarium, Department of Botany, Punjabi University, Patiala (PUN). For meiotic analysis the young and unopened floral buds were fixed in freshly prepared carnoy's fixative (6 alcohol : 3 chloroform : 1 acetic acid $\mathrm{v} / \mathrm{v} / \mathrm{v}$ ) for $24 \mathrm{hrs}$ and then preserved in $70 \%$ alcohol at $4{ }^{\circ} \mathrm{C}$ in the refrigerator. The cytological preparations were made using the squash technique in $2 \%$ acetocarmine. A number of temporary slides were examined to determine the exact chromosome number at different stages and meiotic abnormalities, if any. Pollen fertility was estimated following Marks [6] method using pollen stanibility and well filled nature as a measure of fertility. Shrunken and unstained pollens were considered to be apparently infertile. Average size (equatorial and polar axis) of stained pollen grains has been estimated by taking several readings in case of each populations of $O$. digyna. Photomicrographs of chromosome counts and pollen grains were taken from freshly prepared slides using Nikon 80i Eclipse microscope. For previous chromosome reports various indexes to plant chromosome numbers such as Darlington and Wylie [7], Fedorov [8], Moore [9], Goldblatt [10], Goldblatt and Johnson [11], Kumar and Subramaniam [12] and Khatoon and Ali [13] were consulted.

Results. Present investigation on as many as 14 populations of $O$. digyna from Kashmir and Ladakh Himalaya revealed that the plants show noticeable interpopulation morphological variability. The plants clearly exhibit prostrate and erect habit. Popu-

ISSN 0564-3783. Цитология и генетика. 2014. T. 48. № 1 
Fig. 1. A map showing different collection sites from where Oxyria digyna was collected

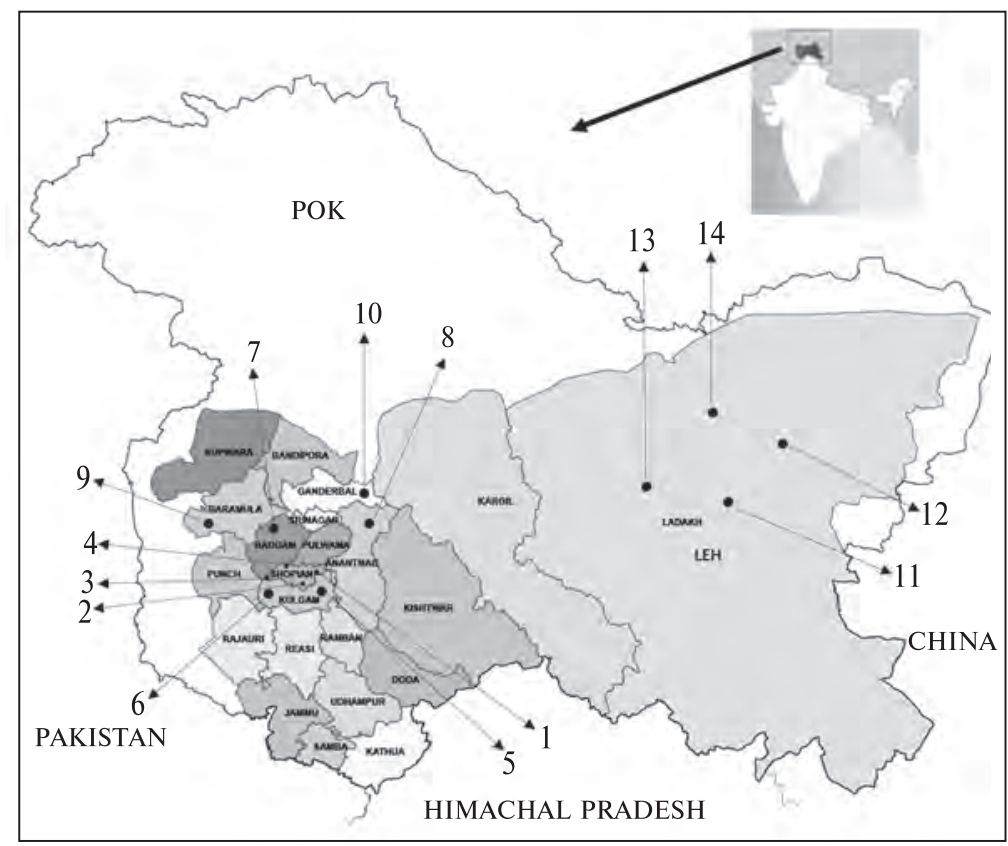

lations of $O$. digyna collected from Hirpora (2450 m), Kongwatan (2600 m), Zogila (3528 m) and Khalsar $(3300 \mathrm{~m})$ are prostrate where those from remaining areas are erect. The data on detailed observation on various morphological parameters are provided in Table 1. The plants showing prostrate habit grow $10-15 \mathrm{~cm}$ in height and form a mat. The plants have small $1.8-2.5 \times$ $\times 2.5-3.0 \mathrm{~cm}(\mathrm{~L} \times \mathrm{B})$ leaves with inflorescence growing up to $5.5 \mathrm{~cm}$ long (Table 1). The erect plants show considerable variation in size and can conveniently be placed under three types viz. small (up to $15 \mathrm{~cm}$ ), medium $(25-50 \mathrm{~cm}$ ) and large $(50-90 \mathrm{~cm})$. The plants showing erect habit have $1.5-3.4 \mathrm{~cm}$ long and $2.0-5.1 \mathrm{~cm}$ broad leaves with inflorescence growing up to $8.5 \mathrm{~cm}$. The colour and texture of leaves and stems also showed interpopulation variations. Populations of $O$. digy-

Table 1. Showing data on different morphological parameters

\begin{tabular}{|c|c|c|c|c|c|c|c|c|c|c|c|}
\hline \multirow{2}{*}{$\begin{array}{l}\text { Accession } \\
\text { number }\end{array}$} & \multirow{2}{*}{$\begin{array}{c}\text { Plant } \\
\text { height, } \\
\mathrm{cm}\end{array}$} & \multirow{2}{*}{ Habit } & \multicolumn{3}{|c|}{ Leaf size, $\mathrm{cm}$} & \multicolumn{3}{|c|}{ Inflorescence } & \multirow{2}{*}{$\begin{array}{l}\text { Stamen } \\
\text { number }\end{array}$} & \multicolumn{2}{|c|}{ Fruit size, mm } \\
\hline & & & Length & Breadth & $\mathrm{L} / \mathrm{B}$ & Number & $\begin{array}{l}\text { Length, } \\
\mathrm{cm}\end{array}$ & $\begin{array}{l}\text { Internode } \\
\text { size, cm }\end{array}$ & & Length & Breadth \\
\hline 55223 & 14 & Prostrate & 2 & 2.5 & 0.80 & 10 & 5.5 & 1.7 & 6 & 2 & 3 \\
\hline 55233 & 32 & Erect & 2.5 & 3 & 0.83 & 7 & 6.9 & 2.5 & 5 & 1 & 3 \\
\hline 55231 & 45 & Erect & 3.4 & 5.1 & 0.66 & 4 & 8 & 4 & 6 & 3 & 4 \\
\hline 55235 & 25 & Erect & 2.5 & 3 & 0.83 & 3 & 4.5 & 1.5 & 6 & 2 & 3 \\
\hline 55226 & 35 & Erect & 3 & 3.7 & 0.81 & 7 & 3.2 & 3.2 & 7 & 1 & 2 \\
\hline 55228 & 15 & Prostrate & 1.8 & 2.7 & 0.66 & 5 & 4 & 2.7 & 6 & 1 & 2 \\
\hline 55227 & 40 & Erect & 1.5 & 2 & 0.75 & 4 & 6.5 & 3.5 & 7 & 3 & 4 \\
\hline 56389 & 15 & Erect & 2 & 2.5 & 0.80 & 5 & 3.5 & 2.7 & 6 & 2 & 3 \\
\hline 55230 & 26 & Erect & 3.2 & 4 & 0.80 & 8 & 4.6 & 2.7 & 6 & 1 & 2 \\
\hline 55229 & 10 & Prostrate & 2.5 & 3 & 0.83 & 3 & 3 & 1.3 & 6 & 1 & 2 \\
\hline 55232 & 10 & Prostrate & 1.8 & 2.7 & 0.66 & 4 & 4 & 2.7 & 6 & 1 & 2 \\
\hline 55234 & 15 & Erect & 2 & 2.5 & 0.80 & 1 & 5 & 1.5 & 6 & 1 & 2 \\
\hline 55225 & 70 & Erect & 2.5 & 3 & 0.83 & 8 & 8 & 3.3 & 5 & 4 & 5 \\
\hline 55224 & 90 & Erect & 2.5 & 3 & 0.83 & 10 & 8.5 & 3.5 & 5 & 3 & 5 \\
\hline
\end{tabular}



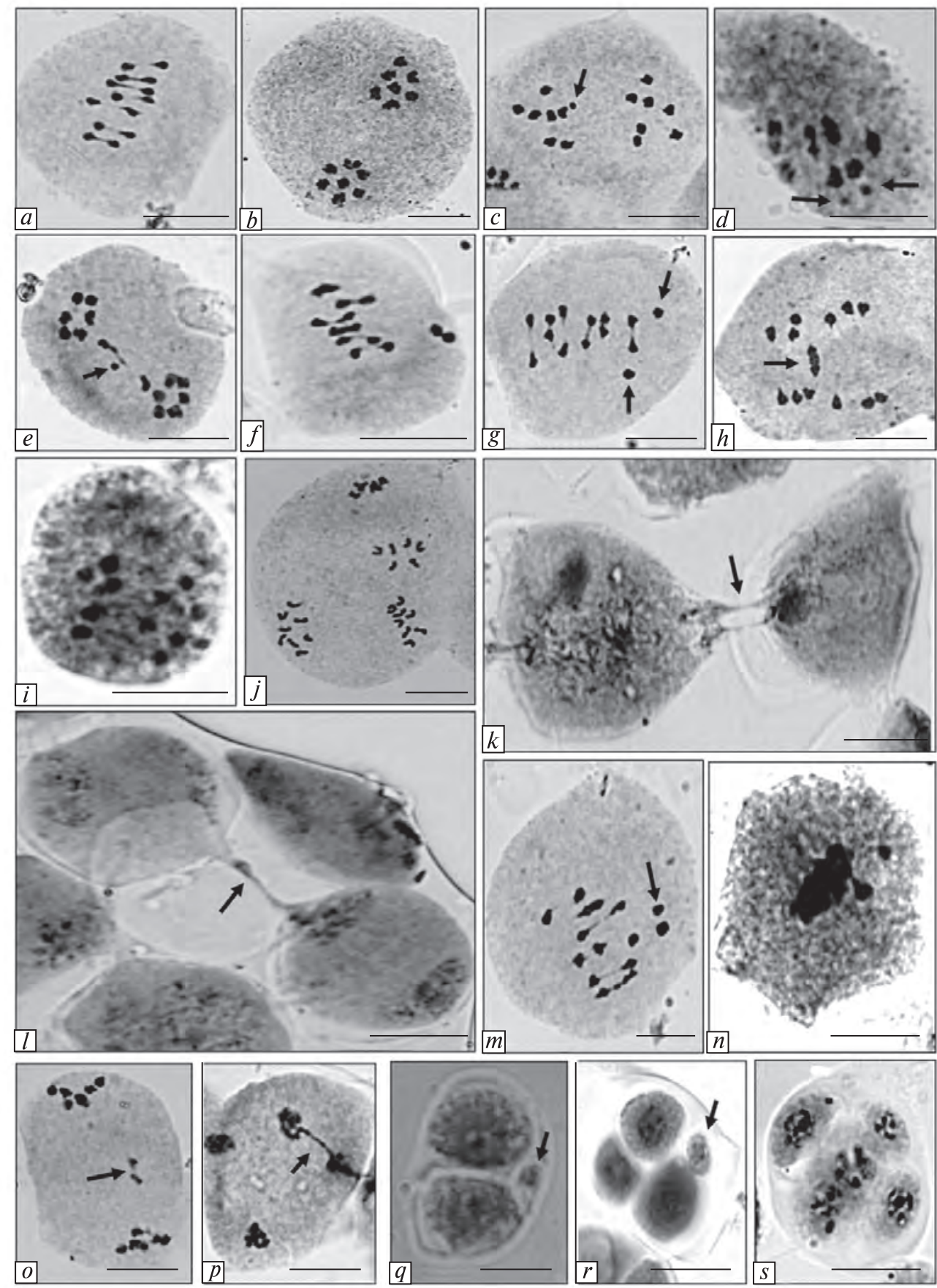

Fig. 2. $a-$ a PMC at metaphase I showing $7_{\text {II }} ; b-$ a PMC with 7:7 distribution at anaphase I; $c-$ a PMC showing 1B chromosome (arrowed); $d-$ a PMC showing 2B chromosomes (arrowed); $e-$ a PMC showing laggard and $\mathrm{B}$ chromosome; $f$ - a PMC with unoriented bivalent at metaphase I; $g$ - a PMC showing early disjunction of one bivalent at metaphase I; $h-$ a PMC showing late disjunction of bivalent at anaphase- $1 ; i-j-$ PMC's showing unequal distribution of chromosomes at anaphase-1and anaphase-II; $k-l-$ PMC's showing chromatin transfer (arrowed); $m-$ a PMC showing extra chromatin material (arrowed); $n-$ a PMC showing stickiness of chromosomes; $o-$ a PMC showing laggards at anaphase-I; $p-$ a PMC showing chromatin bridge at anaphase II; $q-r-$ diad and triad with micronuclei (arrowed); $s-$ a polyad. Scale bar $=10 \mu \mathrm{m}$ 

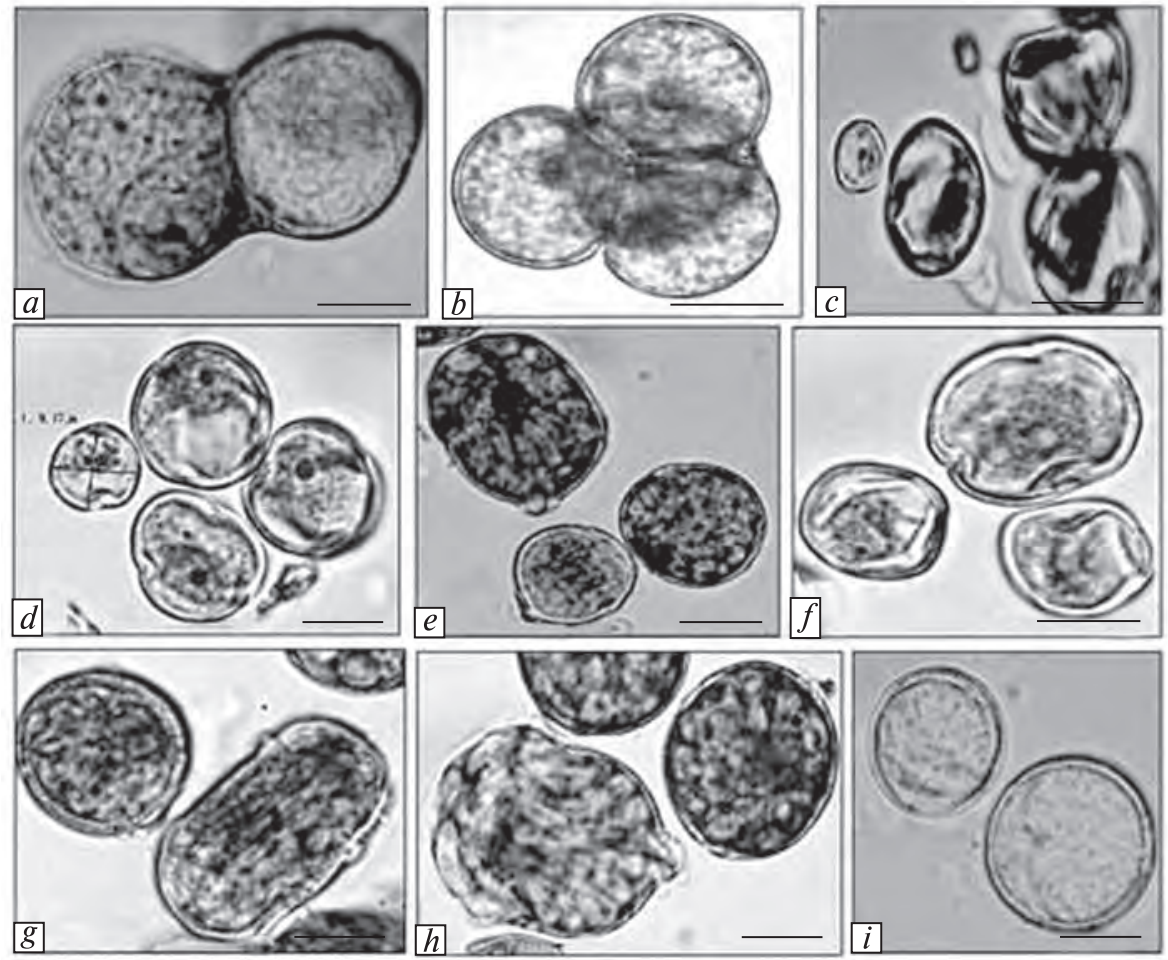

Fig 3. $a-b-$ pollen grains showing fusion and remaining as a unit, $c-h-$ apparently fertile heterogeneously sized pollen grains. (Observe the different sizes and shapes of the pollen grains), $i-$ sterile pollen grain. Scale bar $=10 \mu \mathrm{m}$

$n a$ collected from Zaznar $(3200 \mathrm{~m})$, Lidderwat $(3500 \mathrm{~m})$, and Turtuk $(3100 \mathrm{~m})$ possessed perfect greenish stems with green and shinny leaves. In some populations viz Keller $(2200 \mathrm{~m})$, Yosmarg $(2300 \mathrm{~m})$ the stem and margins of leaf were perfect dark brown. Interestingly, all the prostrate plants possess 6 anthers per flower while in the erect plants the number of anthers per flower varied between 5-7 (majority with 6 anthers per flower). We also present detailed cytological observations made on various populations of $O$. digyna inhabiting different localities of Kashmir Himalaya ranging in altitude from 2200-3528. Information on locality, altitude, geographic coordinates plant accession numbers, meiotic chromosome number, percentage of pollen fertility and average size of pollens of the presently studied populations are provided in Table 2. Meiotic investigations in the plants of all the 14 populations revealed that all share the same chromosome number of $n=7$. This can be confirmed by the presence of 7 bivalents at metaphase-I (Fig. 2, a), equal distribution of chromosomes at anaphase-I (Fig. 2, b). In two populations viz Lidderwat $(3100 \mathrm{~m})$ and Yosmarg $(2300 \mathrm{~m})$ 0-2B chromosomes were detected (Fig. $2, c, d)$. The meiotic course was normal in majority of the populations. As many as six populations of $O$. digyna worked out from Hirpora $(2450 \mathrm{~m})$, Turtuk Ladakh (3100 m), Aharbal (2200 m), Yosmarg $(2300 \mathrm{~m})$, Changmar Leh Ladakh $(3000 \mathrm{~m})$ and Lidderwat $(3100 \mathrm{~m})$ showed meiotic anomalies to a range of 8.94 to $23.13 \%$ PMC's during further course of male meiosis. Few PMC's with un-oriented bivalents at metaphase-I (Fig. 2, f) and non-synchronous disjunction of $1-2$ bivalents was seen in few populations (Fig. 2, $g, h$ ). Unequal distribution of chromosomes was observed at anaphase-I and anaphase-II stages (Fig. 2, $i, j)$ in plants collected from Yousmarg and Lidderwat. As many as five populations exhibited the phenomenon of cytomixis (Table 2). Narrow cytoplasmic channels forming 1-2 chromatin strands involving 2-5 PMC's were observed and the transfer of chromatin material was seen to be both uni and bidirectional (Fig. 2, $k, l$ ). The percentage of PMC's involved in chromatin material transfer 
ranged between $7.14-10.01 \%$. The transfer of chromatin material resulted in the formation of hyperploid cells (Fig. 2, $m$ ). During the present study all the six abnormal populations showed chromosomal stickiness with high percentage $(4.34 \%)$ in the Hirpora population $(2450 \mathrm{~m})$ and lowest $(1.49 \%)$ in the Changmar (3000 m) Leh Ladakh population (Fig. 2, $n$ ). Similarly presence of laggards and bridges at A-I and A-II (Fig. 2,o, $p$ ) were the most common aberrations among all the abnormal populations. Consequent to these abnormalities, microsporogenesis was abnormal characterised by the presence of monads, diads, triads and polyads with or without micronuclei. (Fig. 2, $q-s$ ).

Pollen fertility was reduced in all the abnormal populations $(69-80 \%)$. The above mentioned mei-

Table 2. Information on locality, altitude, geographic coordinates, plant accession numbers, meiotic chromosome number, meiotic abnormalities, percentage of pollen fertility and average size of pollens

\begin{tabular}{|c|c|c|c|c|c|c|c|c|c|c|}
\hline \multirow{2}{*}{ Locality (Altitude, coordinates) } & \multirow{2}{*}{$\begin{array}{l}\text { Acces- } \\
\text { sion } \\
\text { number } \\
\text { (PUN) }\end{array}$} & \multirow{2}{*}{$n$} & \multicolumn{6}{|c|}{ PMCs with meiotic abnormalities, $\%$} & \multirow{2}{*}{$\begin{array}{l}\text { Pollen } \\
\text { ferti- } \\
\text { lity, } \\
\%\end{array}$} & \multirow{2}{*}{$\begin{array}{l}\text { Average pollen } \\
\text { size, } \mu \mathrm{m}\end{array}$} \\
\hline & & & CYM & STC & UOB & BRG & LAG & MPT & & \\
\hline $\begin{array}{l}\text { Shopian: Hirpora, } 2450 \mathrm{~m} \text {, } \\
33^{\circ} 47^{\prime} \mathrm{N} 74^{\circ} 45^{\prime} \mathrm{E}\end{array}$ & 55223 & 7 & 7.60 & 4.34 & 2.17 & 5.43 & 6.52 & - & 73.91 & $\begin{array}{l}22.31 \times 21.68, \\
17.20 \times 16.71\end{array}$ \\
\hline $\begin{array}{l}\text { Shopian: Dhobijan, } 3000 \mathrm{~m} \text {, } \\
33^{\circ} 37^{\prime} \mathrm{N} 74^{\circ} 32^{\prime} \mathrm{E}\end{array}$ & 55233 & 7 & - & - & - & - & - & - & 96.95 & $16.74 \times 15.34$ \\
\hline $\begin{array}{l}\text { Shopian: Zaznar, } 3200 \mathrm{~m} \text {, } \\
33^{\circ} 38^{\prime} \mathrm{N} 74^{\circ} 46^{\prime} \mathrm{E}\end{array}$ & 55231 & 7 & - & - & - & - & - & - & 95.04 & $16.61 \times 15.68$ \\
\hline $\begin{array}{l}\text { Shopian: Keller, } 2200 \mathrm{~m} \text {, } \\
33^{\circ} 43^{\prime} \mathrm{N} 74^{\circ} 83^{\prime} \mathrm{E}\end{array}$ & 55235 & 7 & - & - & - & - & - & - & 98.07 & $16.70 \times 15.87$ \\
\hline $\begin{array}{l}\text { Kulgam : Aharbal, } 2200 \mathrm{~m} \text {, } \\
33^{\circ} 38^{\prime} \mathrm{N} 74^{\circ} 47^{\prime} \mathrm{E}\end{array}$ & 55226 & 7 & 9.09 & 3.89 & 2.59 & 7.79 & 6.49 & - & 70.12 & $\begin{array}{l}28.79 \times 27.91 \\
22.59 \times 19.91 \\
16.44 \times 15.53\end{array}$ \\
\hline $\begin{array}{l}\text { Kulgam : Kongwatan, } 2600 \text { m, } \\
33^{\circ} 36^{\prime} \mathrm{N} 74^{\circ} 46^{\prime} \mathrm{E}\end{array}$ & 55228 & 7 & - & - & - & - & - & - & 98.09 & $16.87 \times 15.86$ \\
\hline $\begin{array}{l}\text { Badgam: Yosmarg, } 2300 \mathrm{~m} \text {, } \\
33^{\circ} 47^{\prime} \mathrm{N} 74^{\circ} 39^{\prime} \mathrm{E}\end{array}$ & 55227 & $7+0-2 B$ & 10.01 & 4.28 & - & 7.14 & 5.71 & 2.85 & 70.01 & $\begin{array}{l}30.11 \times 29.71 \\
24.93 \times 23.67 \\
17.55 \times 16.54\end{array}$ \\
\hline $\begin{array}{l}\text { Anantnag: Lidderwat, } 3500 \mathrm{~m} \text {, } \\
4^{\circ} 04^{\prime} \mathrm{N}, 75^{\circ} 14^{\prime} \mathrm{E}\end{array}$ & 56389 & $7+0-1 \mathrm{~B}$ & 7.14 & 2.85 & - & - & 4.28 & 5.71 & 73.33 & $\begin{array}{l}27.80 \times 26.97 \\
16.06 \times 15.74 \\
5.29 \times 4.28\end{array}$ \\
\hline $\begin{array}{l}\text { Baramulla: Tangmarg, } 2500 \mathrm{~m} \text {, } \\
34^{\circ} 32^{\prime} \mathrm{N}, 25^{\circ} 17^{\prime} \mathrm{E}\end{array}$ & 55230 & 7 & - & - & - & - & - & - & 97.10 & $16.60 \times 15.57$ \\
\hline $\begin{array}{l}\text { Ganderbal: Zogila, } 3528 \mathrm{~m}, \\
34^{\circ} 16^{\prime} \mathrm{N}, 75^{\circ} 28^{\prime} \mathrm{E}\end{array}$ & 55229 & 7 & - & - & - & - & - & - & 96.09 & $17.79 \times 16.68$ \\
\hline $\begin{array}{l}\text { Leh: Khalsar, } 3300 \mathrm{~m} \text {, } \\
34^{\circ} 31^{\prime} \mathrm{N}, 77^{\circ} 41^{\prime} \mathrm{E}\end{array}$ & 55232 & 7 & - & - & - & - & - & - & 98.53 & $17.29 \times 16.25$ \\
\hline $\begin{array}{l}\text { Leh: Changmar, } 3000 \mathrm{~m} \text {, } \\
34^{\circ} 49^{\prime} \mathrm{N}, 77^{\circ} 05^{\prime} \mathrm{E}\end{array}$ & 55234 & 7 & - & - & 1.49 & - & 4.47 & 2.98 & 80.59 & $\begin{array}{l}21.06 \times 20.05 \\
16.72 \times 15.32\end{array}$ \\
\hline $\begin{array}{l}\text { Leh: Bogdan, } 2900 \mathrm{~m} \text {, } \\
34^{\circ} 48^{\prime} \mathrm{N}, 77^{\circ} 02^{\prime} \mathrm{E}\end{array}$ & 55225 & 7 & - & - & - & - & - & - & 97.06 & $16.54 \times 15.59$ \\
\hline $\begin{array}{l}\text { Leh: Turtuk, } 3100 \mathrm{~m} \text {, } \\
34^{\circ} 50^{\prime} \mathrm{N}, 76^{\circ} 49^{\prime} \mathrm{E}\end{array}$ & 55224 & 7 & 9.75 & 3.65 & 2.43 & 6.09 & 7.31 & 3.65 & 69.51 & $\begin{array}{l}25.23 \times 23.57 \\
17.57 \times 16.86 \\
11.56 \times 10.23\end{array}$ \\
\hline
\end{tabular}

Note. CYM - cytomixis, STC - stickiness, UOB - un-oriented bivalent, BRG - bridge, LAG - laggard, MPT multipolarity. 
otic irregularities lead to the formation of heterogenous sized apparently fertile pollen grains which can be categorised into large, small and normal sized pollens (Table 2). Some pollen grains, though in small frequency could not complete their cytokinesis after T-II stage of meiosis and therefore remained together as a unit (Fig. 3, $a, b$ ). The occurrence of large sized pollen grains was observed in Aharbal (4.71\%), Yosmarg $(5.91 \%)$ and Liderwat (5.93\%) populations along with normal sized pollen grains. These large pollen grains might be un-reduced or hyperploid in nature. The diameter of such pollen grains ranged from $27.80 \times 26.97$ to $30.11 \times$ $\times 29.71 \mu \mathrm{m}$, while the diameter of the normal sized pollen grains was $15.53 \times 16.41 \mu \mathrm{m}$. Besides, the normal pollen grains smaller pollen grains $(5.29 \times$ $\times 4.28 \mu \mathrm{m}$ ) were also present. It was interesting to see that in Aharbal and Yosmarg populations a small percentage of pollen grains also differed morphologically. The different shapes of pollen grains observed were round, oval and elliptical (Fig. 3, $c-h$ ).

Discussion. Oxyria is a monotypic genus and exhibits morphological and chromosomal differences. The present diploid chromosome number of $n=7$ for the species is the first report from India. It is also note worthy that the $\mathrm{B}$ chromosomes $(0-2 \mathrm{~B})$ have been reported for the first time in the genus. Earlier studies revealed $2 n=14,28,42$ (diploid, tetraploid and hexaploid cytotypes) [13-19].

B chromosomes can be present or absent in different individuals within a population and do not pair or recombine with any of the A chromosomes during meiosis [20]. It is believed that B chromosomes may have arisen by the fragmentation of A chromosomes or by a greater degree of heterochromatinization [21]. Generally it is accepted that B chromosomes do not have any effect on the growth and development of plants, but it is now shown that pollen abortion in Ornithogalum candatum is related to B chromosomes [22]. It seems that there is no correlation between $\mathrm{B}$ chromosomes and pollen sterility.

Meiotic abnormalities. Present study has revealed the following meiotic abnormalities in this species.

Cytomixis in PMCs. Migration of chromatin material among adjacent meiocytes occurs through cytoplasmic connections originating from the plasmodesmata formed within the anther tissues [23]. The role of cytomixis in plant evolution is considered an additional mechanism for the origin of aneuploidy and polyploidy as it results in the formation of unreduced pollen grains as reported in several plant species [23-25]. In some cases, cytomixis may lead to the migration of whole chromatin among neighbouring meiocytes and lead to the formation of un-reduced gametes. In the present case, hyperploid nature was seen in some PMC's and the product of such PMC's in these individuals yield variable sized fertile and sterile pollen grains.

Chromosome stickiness. Chromosome stickiness is characterised by chromosome clustering during different phases of cell cycle and it ranged from a mild phenomenon involving a few chromosomes to an extensive one involving the entire chromosome complement. Genetic and environmental factors as well as genomic-environmental interactions have been considered to be the reason for chromosome stickiness in different plant species [26, 27].

Spindle abnormalities. Spindles play a crucial role in chromosome alignment during metaphase [25]. Any disturbance in the spindle apparatus may result in the random dis-orientation of chromosomes in the PMC's. Multipolar spindles also produce un-balanced and sterile gametes. Environmental influence and genotypic interactions have been seen responsible for abnormal spindle formation [26].

Non-synchronous disjunction. Generally speaking, different chromosomes of a complement disjunct almost simultaneously, but in some taxa, non-synchronization in the disjunction of bivalents have been reported. These anomalies in the chromosome separation might be due to different rates of terminalisation of various chromosomes of a complement [28], changed homology of chromosomes [29], or absence of coordination between chromosome and spindle [30]. Sometimes due to late disjunction, bivalents lag behind forming micronuclei which ultimately lead to abnormal microsporogenesis. As a consequence of late disjunction of bivalents bridges are often noticed at anaphases and telophases due to interlocking of chiasmata. The delayed separation of some bivalents in the presently investigated species caused irregular distribution of chromosomes at A-I $(8+$ $+6)$ and A-II $(8+8+6+6)$. This phenomenon can be considered of immense cytological significance as it can lead to the formation of gametes with $n+1$ or $n-1$ number of chromosomes causing numerical variation in chromosome number. 
Un-reduced (2n) pollen grains. The trend to form $2 n$ gametes in plants is highly variable and it varies among individuals within a single taxonomic group or even among flowers of an individual plant [31]. The production of unreduced gametes is heritable, governed by many genes and increases with increasing environmental stress, eg. Frost, wounding, herbivory, water deficit and lack of nutrients [32]. Different cytological mechanisms are responsible for the production of $2 n$ gametes. It has been shown that $2 n$ gametes in Brachiaria brizantha are produced from total absence either of the first or the second cytokinesis [33]. Further, influence of seasonal and environmental factors such as high and low temperature on $2 n$ gamete formation have been shown [31]. Besides, cytomixis might have produced un-reduced pollen grains in this species. Different methods (morphological, flow cytometery, cytological) have been used to detect $2 n$ gametes. The most direct method of screening for $2 n$ pollen involves the examination of the range of the size of pollens produced by an individual, as with increase in DNA content the cell volume increases which in turn influence the pollen diameter.

Although the cytological status of these heterogenous sized pollen grains could not be ascertained but certainly their role in the production of aneuploid and polyploid plants could not be ruled out, because of the apparent fertile nature of these pollen grains.

The authors are grateful to the University Grants Commission, New Delhi for providing financial assistance under the DRS SAP III and DST programmes. Thanks are also due to the Head, Department of Botany, Punjabi University, Patiala for necessary laboratory facilities.

\section{Umer Farooq, M.I.S. Saggoo}

\section{ЦИТОМОРФОЛОГИЧЕСКИЕ ИССЛЕДОВАНИЯ OXYRIA DIGYNA HILL. ИЗ КАШМИРА (ГИМАЛАИ, ИНДИЯ)}

Приводятся детальные цитоморфологические исследования Oxyria digyna Hill из Кашмира (Гималаи, Индия). Все 14 изученных популяций являются диплоидными, где $x=7$. Из них в двух популяциях впервые описаны 0-2B хромосомы, тогда как шесть популяций сильно различались по своим мейотическим характеристикам. Аномалии мейоза при микроспорогенезе включали цитомиксис, несинхронное рас- хождение некоторых бивалентов, задержки и мосты в анафазах и телофазах. Возникающий в связи с этим аномальный микроспорогенез приводит к формированию диад, триад и полиад как с микроядрами, так и без них. Общим эффектом является снижение фертильности пыльцы. В некоторых популяциях наблюдали нередуцированные пыльцевые зерна, которые по величине значительно отличались от нормальных. В популяциях Aharbal и Yosmarg некоторые пыльцевые зерна отличались морфологически. Оставшиеся восемь популяций проявляли нормальный ход мейоза, нормальный микроспорогенез и высокий процент фертильности пыльцы $(95,09-$ $99,09 \%)$.

\section{REFERENCES}

1. Pullaiah T. Encyclopaedia of world medicinal plants. New Delhi : Regency publ., 2006. - Vol. I - 2442 p.

2. Chauhan N.S. Medicinal and aromatic plants of Himachal Pradesh. - New Delhi : Indus publ., 1999. $632 \mathrm{p}$.

3. Ballah B., Churasia O.P. Medicinal plants of cold desert Ladakh used in the treatment of stomach disorders // Indian J. Tradit. Know. - 2009. - 8. P. 185-190.

4. Rana M.S., Samant S.S. Diversity, indigenous uses and conservation status of medicinal plants in Manali wild life sanctuary, North West Himalaya // Indian J. Tradit. Know. - 2011. - 10. - P. 439-459.

5. Crawford R.M.M. Plants at the margin : Ecological limits and climate change. - Cambridge : Univ. press, 2008. - 494 p.

6. Marks G.E. An aceto-carmine glycerol jelly for use in pollen-fertility counts // Stain Tech. - 1954. 29, № 5. - P. 277.

7. Darlington C.D., Wylie A.P. Chromosome atlas of flowering plants. - London : Allen and Unwin, 1995. $-519 \mathrm{p}$.

8. Fedorov A.N. Chromosome numbers of flowering plants. - Leningrad : Acad. Sci. USSR Komarov Bot. Inst., 1974.

9. Moore R.J. Index to plant chromosome numbers. 1967-1971, 1972. 1973-1974 // Regnum Veg., 90, 91, 96. 1973, 1974, 1977.

10. Goldblatt $P$. Index to plant chromosome numbers 1975-1978, 1979-1981, 1982-1983, 1984-1985. Monographs in systematic Botany. Missouri Bot. Garden, USA. Vols. 5, 8, 13, 23. 1981, 1984, 1985, 1988.

11. Goldblatt P., Johnson D.E. Index to plant chromosome numbers 1986-1987, 1988-1989, 1990-1991, 19921993, 1994-1995, 1996-1997, 1998-2000, 20012003. Monographs on Systematic Botany. Missouri Botanical Garden, USA. Vols. 30, 40, 51, 58, 69, 81, 94, 106. 1990; 1991; 1994; 1996; 1998; 2000; 2003; 2006. 


\section{Cytomorphological investigations in Oxyria digyna Hill. from the Kashmir Himalaya, India}

12. Kumar V., Subramaniam B. Chromosome Atlas of flowering plants of the Indian subcontinent. Vol. I. Dicotyledon. - Calcutta : BSI, 1986. - 1095 p.

13. Khatoon S., Ali S.I. Chromosome Atlas of the Angiosperms of Pakistan. - Karachi, 1993. - 232 p.

14. Dalgaard $V$. Chromosome numbers in some vascular plants from the Disko Bugt area (West Greenland) // Willdenowia, 1988. - 18. - P. 243-252.

15. Huber $W$., Baltisberger M. IOPB chromosome data 1. Int. Organ // Pl. Biosyst. Newslett. (Zurich). - 1989. 13. - P. 19-20.

16. Krogulevich R.E. Kariologicheskij analiz vidov Flory Vostochnogo Sajana // Flora Pribajkal'ja. - Novosibirsk : Nauka, 1978. - P. 19-48 (Russian).

17. Dobes C., Vitek E., Buttler K.R. Documented chromosome number checklist of Austrian vascular plants. Vienna, 2000. - $642 \mathrm{p}$.

18. Murin A., Haberova I., Zamsran C. Karyological studies of some species of the Mongolian flora // Folia Geobot. Phytotax. - 1980. - 15. - P. 395-405.

19. Zhukova P.G., Petrovsky V.V. Chromosome numbers and taxonomy of some plant species from the northern Asia regions // Bot. Zurn. - 1987. - 72. P. 1617-1624.

20. Jones R.N., Huben A. B-chromosome in plants: escapees from the A-chromosome genome? // Trends Plant Sci. - 2003. - 8. - P. 417-423.

21. Parker J.S., Jones G.H., Edger L.A., Whitehouse C. The population cytogenetics of Crepis capillaris 3. B-chromosome effects on meiosis // Heriditas. - 1990. 64. - P. 377-385.

22. Hui C., Shamshi H.I., Haijum Z. et al. Cytological evidence of pollen abortion in Ornithogalum caudatum Ait // Afr. J. Biotech. - 2011. - 10. P. 14061-14066.

23. Falistoco E., Tosti T., Falcinelli M. Cytomixis in pollen mother cells of diploid Dactylis, one of the origins of $2 n$ gametes // J. Heredity. -1995 . -86 . P. $448-453$.
24. Latoo S.K., Khan S., Bamotra S., Dhar A.K. Cytomixis impairs meiosis and influences reproductive success in Chlorophytum comosum (Thunb.) Jacq.: An additional strategy and possible implications // J. Biosci. 2006. - 31. - P. 629-637.

25. Shabrangi A., Sheidai M., Majd A. et al. Cytological abnormalities caused by extremely low frequency electromagnetic fields in Canola // Sci. Asia. - 2010. 36. - P. 292-296.

26. Nirmala A., Rao P.N. Genesis of chromosome numerical mosacism in higher plants // Nucleus. 1996. - 39. - P. 151-175.

27. Baptista-Giacomelli F.R., Pagliarini M.S., Almeida J.L. Meiotic behaviour in several Brazilian oat cultivars (Avena sativa L.) // Cytologia. - 2000. - 65. P. 371-378.

28. Darlington C.D. Recent advances in cytology. - London : Churchill \& Co., 1937.

29. Koul M.L.H. Cytogenetic of polyploids. 4. Cytology of photoperiodic races and cytotypes of Ageratum conyzoides L. // Cytologia. - 1971. - 36. - P. 421434.

30. Sharma A. The Chromosomes. - New Delhi : Oxford \& IBH Publ. Co., 1976.

31. Bretagnolle F., Thomson J.D. Gametes with the somatic chromosome number: mechanisms of their formation and role in the evolution of autopolyploid plants // New Phytol. - 1995. - 192. - P. 1-22.

32. Husband B.C. The role of triploid hybrids in the evolutionary dynamics of mixed ploidy populations // Biol. J. Linn. Soc. - 2004. - 82. - P. 537-546.

33. Risso-Pascotto C., Pagliarini M.S., Valle C.B., MendesBonato A.B. Chromosome number and microsporogenesis in pentaploid accession of Brachiaria brizantha (Gramineae) // Plant Breed. - 2003. - 122. P. 136-140. 